\title{
Rules, Standards, and Such
}

Kevin M. Clermont

\section{Table of Contents}

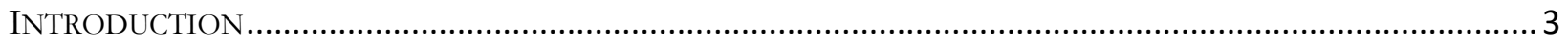

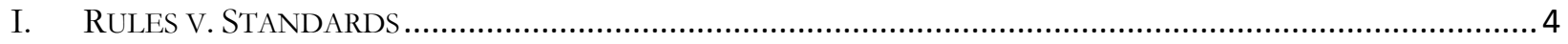

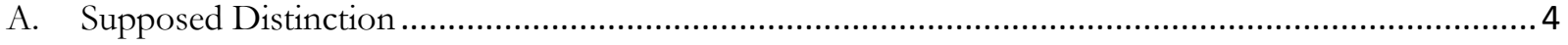

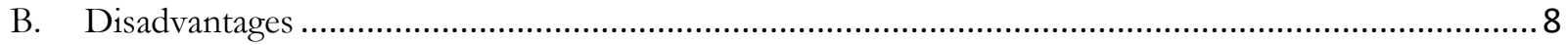

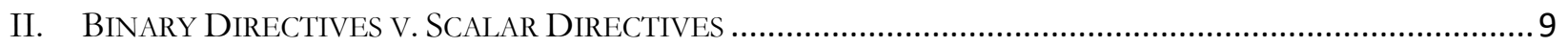

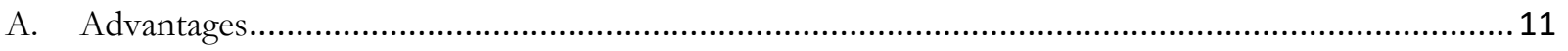

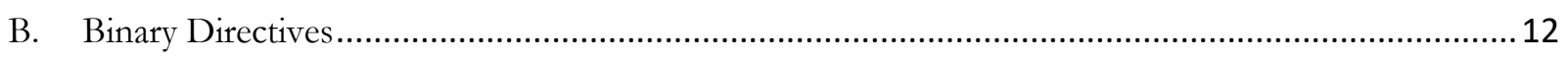

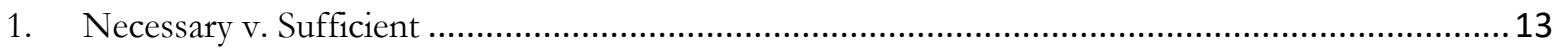

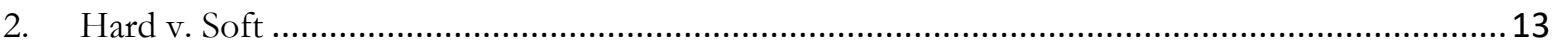

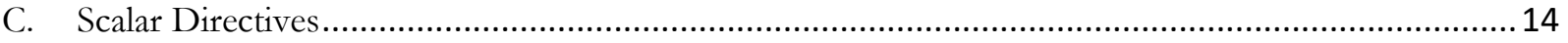

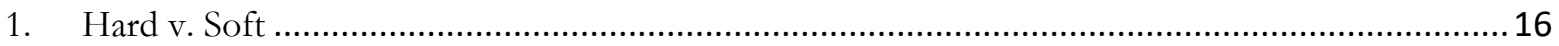

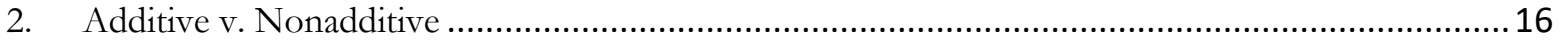

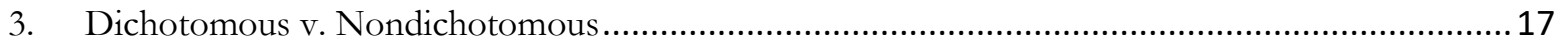

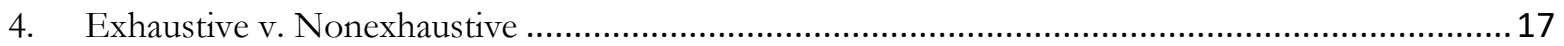

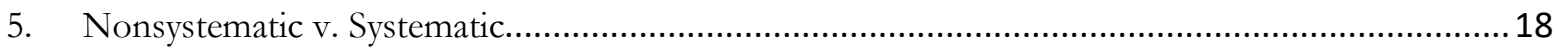

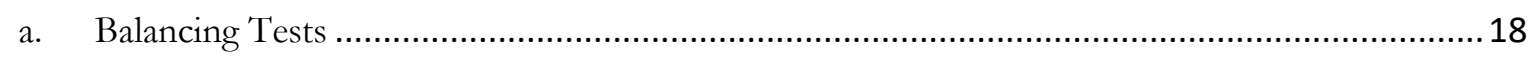

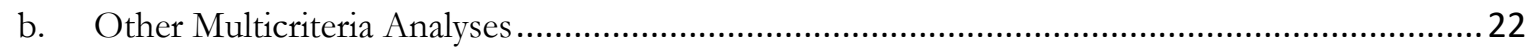

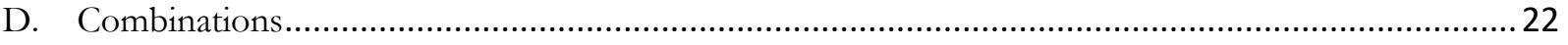

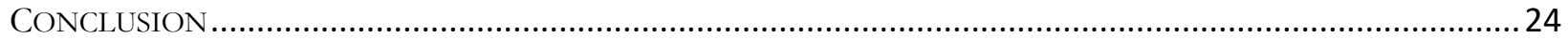

Abstract

This Article aims to create a complete typology of the forms of decisional law. Distinguishing "rules" from "standards" is the most commonly attempted jurisprudential line, roughly drawn between nonvague and vague. But no agreement exists on the dimension along which the rule/standard terminology lies, or on where the dividing line on the continuum lies. Thus, classifying in terms of vagueness is itself vague. Ultimately it does not aid legal actors in formulating or applying the law. The classification works best as an evocative image.

A clearer distinction would be useful in formulating or applying the law. For the law-applier, it would be more useful if expressly focused on whether the law-giver was trying to pin things down

* Ziff Professor of Law, Cornell University. Emad Atiq, Ed Cavanagh, Adrienne Clermont, Zach Clopton, John Leubsdorf, and Emily Sherwin gave me very helpful comments. 
and thus narrow the room for discretion. It would be even more useful if it had helped that law-giver to think about how to pin things down.

This better top-level distinction lies between binary and scalar directives. If the directive comprises a checklist of one or more yes/no conditions, then it is a binary directive. If instead the directive calls for consideration of multivalent factors, it is a scalar directive. Binary/scalar is a superior distinction for analysis. First, binary/scalar is a clean distinction. Second, it is a telling distinction that represents a significant difference between the components that compose the law. Third, it tells the law-applier much about whether the law-giver tried to pin things down. Fourth, it conveys a better sense of the tools at hand for the law-giver's pinning down the law-applier, and thus enables the tools' deployment in an optimal way. Fifth, it allows the drawing of meaningful subdivisions that bring to the fore the choices in shaping that law: for example, one such subtype of scalar directives is a true balancing test, which explicitly or implicitly presents an exhaustive listing of quantifiable and commensurable considerations to be scaled and weighed against one another-and offers a route to retrieving control in the application of any law that has to be expressed as a scalar directive.

Parenthetically, a running example to illustrate the superiority of binary/scalar comes from injunctive relief. The test for a temporary restraining order was the supposedly binary condition of "irreparable harm," but it has disintegrated in practice to the prevailing test for a preliminary injunction. The diversity among the tests for preliminary injunctions reveals the essential struggle between the necessary flexibility for infinitely variable situations and the need for appropriately corralling the judges' discretion. From ancient roots of unrestrained discretion, the test for a preliminary injunction has evolved in recent decades from a sequential test of four supposedly binary conditions to the indefiniteness of a sliding-scale approach that balances the so-called four factors, back to a hopeless stab at crispness in the form of the alternatives test, which tries to state alternative combinations of situational facts that warrant provisional relief. The best test emerges as a systematized form of scalar directive - a true balancing test - that asks if the expected costs of a potentially wrongful denial exceed the expected costs of a potentially wrongful grant of a preliminary injunction. The inadequacy of the current rule/standard distinction for this analysis reveals itself in the fact that it would probably categorize all the competing preliminary injunction tests as "standards."

In sum, this Article does not propose casting rule/standard aside as a way of classifying decisional law. Instead, it proposes adopting binary/scalar as the way to define rules and standards. 


\section{INTRODUCTION}

Without form, substance is but mud. Or so it is said. ${ }^{1}$ Accordingly, my aim in this Article is to create a complete typology of the forms of decisional law. To be complete, it needs to be a top-down organizational structure that divides the whole subject. Thereafter, it needs to make optimally expressive subdivisions.

By "decisional law," I mean any law that could ultimately direct or guide a decision rendered by an adjudicator or other law-applier. The decision might be judgment by a judge, but it also could be a decision by any other legal actor in the executive to do some act, or by a private citizen to treat some agreement as a binding contract, or whatever. As mine is an inclusive definition, ${ }^{2}$ my coverage extends to both substantive and procedural doctrine. Nonetheless, my extended illustrations will concentrate on the procedural side, and indeed injunctive relief will be major focus of the illustrations. Civil procedure lies within my expertise and cuts across most substantive fields. Moreover, maintaining a focus will lend a consistency of illustration.

The "forms" of concern are the forms into which law-givers (be it constitution, legislature, delegatee, or court) put law for decision by a law-applier. In the abstract, the conceivable variations on form are virtually unlimited. But in practice, given law's twin missions of law-giving and lawapplying, only certain forms appear. Because legal directives are functions that take conditions to consequence, the existing forms are all variations on if-then, that is, condition-consequence (or antecedent-consequent). ${ }^{3}$ Thus, all decisional law can be restated as "if conditions, then consequence." " The conditions are essentially factual, in a broadly conceived sense. They might be yes/no; but they can be variables measured on a scale, such as matters of degree, opinion, or normative values, some of which might be called mixed facts. ${ }^{5}$ Consequences can be and are varied. They embody all the outputs of the legal system.

The law-applier (be it a judge or any other legal actor, public or private) determines the satisfaction of the conditions by a more or less formal factfinding process. That process could involve generating evidence-based beliefs in the truth of facts and then testing them by the standard of proof, or it could require the factfinder's best judgment of the condition's placement on a scale. ${ }^{6}$ The lawapplier then applies the law by deductive syllogism to reach a consequence.

1 See Thomas Ainsworth, Form vs. Matter, in STANFord EnCyClopedia OF Philosophy (Edward N. Zalta ed., 2016), https://plato.stanford.edu/entries/form-matter/; Sean Gregory, The Brief, Time, Dec. 17, 2018, at 15 (quoting John McPhee) ("Sooner or later, you have to have a sense of structure, or all you've got is a bowl of spaghetti."). But cf. JACK KEROUAC, THE DHARMA Bums 14 (1958) ("It's only through form that we can realize emptiness."). On the importance of the formal component of law, see generally RoBERT S. SUMmERS, FORM AND FUNCTION IN A LEGAL SYSTEM-A GENERAL STUDY 3-36 (2006). On the substantive component, see generally Howard Robinson, Substance, in STANFORD ENCYCLOPEDIA OF PHILOSOPHY (Edward N. Zalta ed., 2018), https://plato.stanford.edu/entries/substance/.

${ }^{2} \mathrm{My}$ definition is not all-inclusive, however. I do not include descriptive rules or even prescriptive rules, like "Thou shalt not steal.” And I include only legal provisions. See FrEDERICK SCHAUER, PLAYING BY THE RULES: A PHILOSOPHICAL EXAMINATION OF RUlE-BASED DECISION-MAKING IN LAW AND LIFE 1-12 (1991).

3 See Dorothy Edgington, Indicative Conditionals, in STANFORD ENCYCLOPEDIA OF PHILOSOPHY (Edward N. Zalta ed., 2014), https://plato.stanford.edu/entries/conditionals/ ("Despite intensive work of great ingenuity, this remains a highly controversial subject.").

4 See Pierre Schlag, Rules and Standards, 33 UCLA L. REV. 379, 381 (1985) ("It is possible to look at positive law (constitutions, statutes, judicial opinions, and administrative orders) as a series of directives. The formula for a legal directive is 'if this, then that.' A directive thus has two parts: a 'trigger' that identifies some phenomenon and a 'response' that requires or authorizes a legal consequence when that phenomenon is present.").

5 The definition of "mixed facts" for appeal purposes or for jury right differs. See RICHARD H. FIELD, BENJAMIN Kaplan \& Kevin M. Clermont, Materials For a Basic Course in Civil Procedure 1555-63, 1628-31 (12th ed. 2017) (defining "fact" for jury and for appeal).

${ }^{6}$ In all events, cognition in factfinding remains pretty much a black box. The actual process may be rational or intuitive, although it should involve so-called critical common sense. It may proceed atomistically or holistically. The best view based on psychology, and introspection, posits that factfinders proceed to a stab at judgment on the satisfaction of 
There is much this Article is not trying to do. It is not categorizing law by source, purpose, or function. It is not dealing with either the law or the practice for making decisional law. Hence, it is not worried about the appropriate content of decisional law or, at least as a central question, when one form of decisional law or another is appropriate.

Instead, this Article's aim is a typology of the forms of decisional law. The focus will be on form as a means of constraint in law's application. I shall critique the usual rule/standard distinction in Part I, and then introduce an alternative typology in Part II.

\section{RULES V. STANDARDS}

Distinguishing "rules" from "standards" is the most common jurisprudential line attempted with regard to decisional law, because most theorists think it is a particularly useful one. ${ }^{7}$ They prefer it to other conceivable dimensions along which to make distinctions for the purpose of typology. ${ }^{8}$

\section{A. Supposed Distinction}

How do rules differ from standards? It ends up rather vague. ${ }^{9}$ A standard guides decision by giving some explicit or implicit formula of considerations, with the decisional law being given most of its content during its application. A standard might do no more than list a few considerations for the adjudicator or other decider somehow to take into account in deciding how to handle a difficult problem in the context of a particular case, or it might only suggest considerations by some condition such as "unreasonableness." A rule in the contrary sense is a largely determinate statement that acquires most of its content during drafting. It goes far toward dictating in advance the outcome of the problem, leaving to the adjudicator only the finding of facts without worrying about the purpose of the rule or about moral considerations.

Listing other characteristics of rules and standards might help making the distinction. On the one hand, standards tend to be easier to draft. Their application can be more precise in reaction to the particular case, avoiding the costs of over- and under-inclusion. They need less amendment to fit the changing environment over time. However, these characteristics are only generally true, as some standards can be quite rule-like in practice. On the other hand, rules are often costly to promulgate, but less costly for courts and people to apply, so that the economics tend to favor employing rules for decisional law that will require frequent application in recurring situations. ${ }^{10}$ Rules tend to produce more predictable and consistent application, and they usually convey more information, with the result

each condition largely by intuition and in an approximate and nonquantified way. See Kevin M. Clermont, Staying Faithful to the Standards of Proof, 104 CORNELL L. REV. 9-10 (forthcoming 2019) (analyzing the factfinding process).

7 See Russell B. Korobkin, Behavioral Analysis and Legal Form: Rules vs. Standards Revisited, 79 OR. L. REV. 23, 23 (2000) ("The choice of legal form has long been described as a choice between 'rules' and 'standards."); Schlag, supra note 4, at 379, 381-82 ('Every student of law has at some point encountered the 'bright line rule' and the 'flexible standard.' . . . [D]irectives can be general or specific, conditional or absolute, narrow or broad, weak or strong. They can also be rules or standards. Thus, the opposition of rules and standards is one dimension of the form of a legal directive.").

8 See, e.g., Michael Evan Gold, Levels of Abstraction in Legal Thinking, 42 S. ILL. U. L.J. 117, 119 (2018) ("In general, the more persons and transactions to which an issue and its resolution apply, the higher the level of abstraction ....").

9 "Vague" herein means unclearly limited. See Roy Sorensen, Vagueness, in STANFORD ENCYCLOPEDIA OF PhILOSOPHY \ 4 (Edward N. Zalta ed., 2018), https://plato.stanford.edu/entries/vagueness/ ("a term is vague to the extent that it has borderline cases").

10 See Hans-Bernd Schaefer, Legal Rules and Standards, in 3 The Encyclopedia OF Public ChOICE 347, 347-48 (Charles K. Rowley \& Friedrich Schneider eds., 2004). 
that people can better self-regulate ${ }^{11}$ or evade. ${ }^{12}$ Rules better protect rights from erosion over time. ${ }^{13}$ However, rules are sometimes impractical or even impossible to promulgate, as the drafters possess too little knowledge, the permutations for application are too numerous, or the limitations of language impede the task. ${ }^{14}$

In sum, many conflicting considerations affect the choice between rule and standard as currently conceived, leaving the choice largely ad hoc. ${ }^{15}$ That is, no rule exists to choose between rule and standard. The choice of form should turn on a cost-minimization strategy that takes into account the full range of error costs and direct costs. Still, tax laws tend to be rule-dominated, while antitrust likes its standards including its misnamed Rule of Reason. ${ }^{16}$ Conflict of laws has migrated from rules to standards for choice of law, and maybe is on the way back. ${ }^{17}$

Taking a closer look at procedure for more examples, the Federal Rules of Civil Procedure were designed to be a set of general provisions that would be uniform for all substantive and procedural types of cases across the whole nation. ${ }^{18}$ Those goals created pressures on the drafters.

11 See Dale A. Nance, Rules, Standards, and the Internal Point of View, 75 FORDHAM L. REV. 1287 (2006) (arguing for rules over standards, in the interest of self-governance); cf. James G. Wilson, Surveying the Forms of Doctrine on the Bright LineBalancing Test Continuum, 27 ARIZ. ST. L.J. 773, 773-76 (1995) (cataloging other attempts to justify a general bias in favor of either rules or standards).

12 See Nance, supra note 11, at 1309-11; Claire Stamler-Goody, Finding Meaning in Rules and Standards, https://www.law.uchicago.edu/news/finding-meaning-rules-and-standards (discussing Anthony J. Casey's talk on "The Short Happy Life of Rules and Standards": "When the government pre-commits to strict laws, it cannot be subject to ex post bias and twist them in its favor after events have unfolded. Rules have high pre-commitment, while standards' precommitment is low. The flipside of pre-commitment is evasion, Casey added, because when people know the exact content of a law, they are better equipped to find loopholes and evade it for their own benefit.").

13 See Robert G. Bone, The Story of Connecticut v. Doehr: Balancing Costs and Benefits in Defining Procedural Rights, in Civil Procedure STORIES 159, 196 (Kevin M. Clermont ed., 2d ed. 2008) ("the point of a right is that it constrains the sort of reasons that can be used to justify limits").

14 See H.L.A. HART, THE CONCEPT OF LAW 125 (1961) (going beyond the indeterminacy of language to identify two relevant handicaps of the human condition: "The first handicap is our relative ignorance of fact: the second is our relative indeterminacy of aim.”).

15 See Korobkin, supra note 7, at 58-59 ("The normative question of whether to promulgate law in the form of rules or standards seems unanswerable with a rule, even a complex one. Presenting lawmakers with a set of multiple factors to weigh in standard-like fashion is probably all that legal scholars can do."); Wilson, supra note 11, at 842 ("Choosing the proper form is part of a simultaneous equation, which arguably includes at least the following other factors: the plaintiff's interests, defendant's interests, ease of formulating a remedy, nature of the claim (constitutional versus statutory or common law), foreseeable costs and benefits of favoring either party, degree of concern about future abuses by similar parties, nature of those abuses, prior record of similar parties, any relevant statutory or constitutional text, purposes of that text, legislative history, subsequent history, mischief that the text was attempting to cure, structure of the system the text created, judicial competence, role of the judiciary, precedent, judge's personal views and experiences, public opinion, judge's sense of self-confidence, concerns about future discretion, evidentiary problems, and competing legitimate ends, both substantive and judicial process, that judges must try to achieve."); cf. Korobkin, supra note 7, at 58 (bringing in behavioral analysis to supplement economic analysis, but concluding: "Under either approach, an honest analyst without preconceived conclusions must ultimately say that multiple considerations favor each type of legal form, and which form is most desirable will depend on which set of competing costs dominate in a particular fact-specific situation.").

16 See Robert H. Bork, The Rule of Reason and the Per Se Concept: Price Fixing and Market Division, 74 YALE L.J. 775 (1965) (contrasting per se rules).

17 See Neumeier v. Kuehner, 31 N.Y.2d 121, 127 (1972) ("There is, however, no reason why choice-of-law rules, more narrow than those previously devised, should not be successfully developed, in order to assure a greater degree of predictability and uniformity, on the basis of our present knowledge and experience.”); Kermit Roosevelt III, Certainty vs. Flexibility in the Conflict of Laws, in THE CONTINUING RELEVANCE OF PRIVATE INTERNATIONAL LAW AND ITS Challenges ____ (F. Ferrari \& D. Fernandez Arroyo eds., 2019) (“Contemporary (as opposed to modern) choice of law is often rule-based," with narrow rules formulated to optimize systemic and correctness values.). Compare RESTATEMENT (SECOND) OF CONFLICT OF LAWS (AM. LAW INST. 1971) (using standards), with RESTATEMENT OF CONFLICT OF LAWS (AM. LAW INST. 1934) (using broad rules).

18 See Kevin M. Clermont, Principles Of Civil Procedure 51-56 (5th ed. 2018). 
One consequence was brief and simple Federal Rules riddled with gaps. The same pressures pushed the general jurisprudential tenor of the Federal Rules toward standards rather than rules. Still, the Federal Rules fully range along a continuum that goes from standards whose application requires considerable judicial judgment and discretion down to quite determinate rules. Accordingly, Rule 26(b)(2)(C)(i) uses a standard in disallowing discovery that is "unreasonably cumulative," while Rule 4(c)(2) establishes the rule that process may be served by anyone "who is at least 18 years old and not a party." Some of the Rules (e.g., Rule 19 on who should or must be joined as a party) need to be set forth as standards, but other Rules (e.g., Rule 12 on the amount of time to answer) should be in the form of a rule. Most of the other Rules fall in the middle, although some Rules might improve upon the rulemakers' recalling the benefits of either a more standard-like approach or a more rule-like approach.

All that said, no agreement in fact exists on what exactly the rule/standard terminology means, because there is no agreement even as to the dimension along which the distinction lies. ${ }^{19}$ For maximal usefulness, the distinction should focus on some essential difference along one particular dimension. ${ }^{20}$ But what is that dimension? In the dominant discussions, the distinction gets phrased as specific v. general $^{21}$ or ex ante v. ex post. ${ }^{22}$

On the one hand, specific/general in this context refers, albeit counterintuitively, to the form's level of incompleteness in statement. ${ }^{23}$ Confusingly, it does not refer to narrow or broad in coverage, nor to complex or simple in expression. Although these braces of adjectives are among the many possible alternative distinctions among decisional laws that have been used to define rules and standards, ${ }^{24}$ they do not work. The fatal reason is that the usual examples of rules and standards are not distinguishable in these terms. ${ }^{25}$ Both rules and standards can be narrow, broad, simple, or complex. A simple rule, and especially a complex series of rules, could be very broad in application. A complex standard could still be narrow in coverage.

On the other hand, ex ante/ex post posits a definition that turns on whether the real lawmaking is done by the law-giver ex ante or by the law-applier ex post, that is, before or after the actor acts. ${ }^{26}$ Supposedly, rules are specified in advance in a legislative way, while standards leave to the later adjudicator or other decider the work of weighing the standard's considerations. Thus, the ex ante/ex post distinction brings to the fore a comparison of institutional advantages. Yet institutional concerns bear more on how to make decisional law than on how to distinguish rules from standards. ${ }^{27}$

19 See Schlag, supra note 4, at 382 n.16 ('The terms 'rules' and 'standards' do not have clear and fixed meanings in the scholarly literature.”).

20 Professor Schlag said, "The trigger can be either empirical or evaluative, and the response can be either determined or guided." Id. at 382. But he went on to say that, at least as a paradigm, "a rule has a hard empirical trigger and a hard determinate response. . . A standard, by contrast, has a soft evaluative trigger and a soft modulated response.” Id. at 38283. He thus instinctively reduced a $2 \times 2$ distinction to a single dimension.

21 See Barbara Luppi \& Francesco Parisi, Rules Versus Standards, in 7 ENCYCLOPEDIA OF LAW AND ECONOMICS 43, 49 (Gerrit De Geest ed., 2d ed. 2009) (modeling the optimal specificity of laws, with rules having high specificity and standards having low specificity).

22 See Louis Kaplow, Rules Versus Standards: An Economic Analysis, 42 DUKE L.J. 557, 560 (1992) ("the only distinction between rules and standards is the extent to which efforts to give content to the law are undertaken before or after individuals act').

23 See Luppi \& Parisi, supra note 21, at 43 ("Lawmakers can choose the level of incompleteness of the laws that they write by formulating laws with different degrees of specificity.").

24 See Summers, supra note 1, at 136-81 (listing as distinctions: prescriptiveness, completeness, definiteness, generality, structure, encapsulation, and expression); Kaplow, supra note 22, at 560 \& nn.4-5, 565 \& n.13 (giving alternative definitions of rule/standard distinction).

25 See Kaplow, supra note 22, at 586 ("For any standard, consider the actual outcomes that would arise for all possible cases. Now, define the 'rule equivalent to the standard' . . . as that rule which attaches these same outcomes to these cases. Thus, if a standard is compared to the rule equivalent to the standard, the content and level of detail are held constant.").

26 See id. at 586 (distinguishing whether laws should be relatively simple or complex from whether laws are given content ex ante as rules or ex post as standards); cf. Roscoe Pound, Mechanical Jurisprudence, 8 COLUM. L. REV. 605 (1908) (drawing the line between mechanical jurisprudence and discretionary decisionmaking).

27 See Schaefer, supra note 10, at 348-49. 
Indeed, the distinction does not do a perfect job at separating rules from standards. First, the reality in our legal system is that, for lawmaking, before-and-after is always a matter of degree. The distribution of functions to law-givers and law-appliers is mixed too. Even rules leave some of the work in shaping the law to the law-applier. The law-applier can also generate standards in effect, or develop rules, for present and future use and thus also act as law-giver. Second, if the ex ante/ex post distinction were reliable, it would better track the law/fact distinction, at least for rules. As it is, both rules and standards can generate issues of law as well as of fact for the law-applier. Third, and most importantly, some laws that look very much like ex ante rules leave much discretion to the law-applier by virtue of the vagueness of language, while some standards such as a tightly defined balancing test can effectively box in the law-applier. "Rules" can thereby be standards, and "standards" can act like rules.

These two attempts at distinction, specific/general and ex ante/ex post, emphasize respectively the conditions or the consequence of decisional law. The former distinction focuses on whether the conditions have been completely specified. The latter focuses on whether the law determines the consequence before the act. But a focus on the consequence is misplaced. Conditions offer a more effective distinction. The character of the conditions better captures whether the lawgiver has spelled things out to the law-applier. The before-and-after feature would thus fall to a generally correlated attribute of rules and standards.

As to distinguishing among types of conditions, specific/general arguably marks the right direction to go. Its exact path and its signage could be improved. For the purposes of this Article, I shall employ this dimension: The best expression of the essential difference in the nature of the conditions in rules and standards comes in terms of vagueness, with vagueness increasing from rules to standards and so making the conditions less determinative. ${ }^{28}$

A still critical defect of the vagueness dimension is that it remains a spectral distinction, always a matter of degree. The proposed distinction of ex ante/ex post was in part an attempt to forge a clearer dividing line, but it had only limited success in that pursuit. Along the dimension of vagueness, the division might be conveyed by the phrase of hard v. soft forms. ${ }^{29}$

Vagueness may have yet another defect, namely, it could be a multidimensional feature. This helps to explain why authors have not been able to agree on a single criterion to define rule/standard. Some authors indeed use multiple criteria in distinguishing among forms. ${ }^{30}$ Thus, Professor Summers eschewed rule/standard in favor of completeness (having no spaces left in the law) and definitiveness (having fixity and specificity). ${ }^{31}$

Therefore, a distinction between rules and standards in terms of vagueness will itself be an inevitably vague distinction. Moreover, this distinction does not attend to all the variables that influence choice of form, such as institutional capacities. Accordingly, one could prefer any of the many other attempts to define rule/standard. Obviously, they have a lot of overlap. The real takeaway is that commentators do not agree on a definition.

${ }^{28}$ The spectrum culminates in "heaps," an expression that refers to the most hopelessly vague concepts. See Dominic Hyde \& Diana Raffman, Sorites Paradox, in StAnford EnCyClopedia OF PHILOSOPHy \ 1 (Edward N. Zalta ed., 2018), https://plato.stanford.edu/entries/sorites-paradox/ ("The name 'sorites' derives from the Greek word soros, meaning 'heap."').

29 See Lawrence Solum, Legal Theory Lexicon: Rules, Standards, and Principles, http://lsolum.typepad.com/legaltheory/2009/09/legal-theory-lexicon-rules-standards-and-principles.html. Incidentally, Professor Solum calls a single, broad, nonexhaustive consideration a "principle." See id. (giving as an example the principle that one may not benefit from one's own wrong). Professor Dworkin used "principle" in a broad way that subsumed “standard." See Ronald W. Dworkin, The Model of Rules, 35 U. CHI. L. REV. 14, 22-29 (1967).

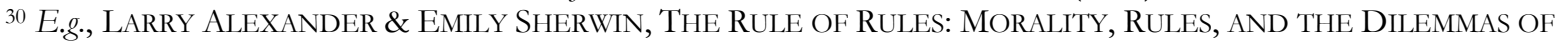
LAW 30 (2001) (defining rules as opposed to standards in terms of determinateness, but also requiring a completeness that settles all questions within the rule's scope).

31 See Summers, supra note 1, at 147-60; cf. P.S. AtTYAH \& ROBERT S. SumMERS, FORM AND SubSTANCE IN ANGLOAMERICAN LAW 75 (1987) (distinguishing, in earlier work, between flexible rules and hard and fast rules). 
Given the difficulty of definition, why then do commentators persist in speaking of rules and standards? The allure of rule/standard comes from its encapsulating the eternally central debate in jurisprudence over the relative values of workable certainty and flexible accuracy. ${ }^{32}$ Rules would specify the operative facts that trigger the consequence, while standards would rely more on the underlying principles and policies as triggers. ${ }^{33}$ Standards would tend to give sensitivity and precision, while rules would tend to give predictability and reliability. The unattainable aim would be to use standards and rules in a way that, while focusing the decisionmaker's attention on all relevant considerations, optimizes the size of the decisionmaker's black box of discretion. ${ }^{34}$

\section{B. Disadvantages}

The shortcomings of rule/standard as a distinction, then, are obvious. First, the dimension along which the distinction is to be drawn is disputed by theorists, as described in the prior section. Perhaps the distinction ends up more of a multidimensional feeling. Second, any defining dimension certainly constitutes a continuum. ${ }^{35}$ There are sharp bright-line rules and relatively vague rules, and there are relatively bright-line (e.g., a tightly defined balancing test) and very vague (e.g., impose consequence if justice so requires) standards. Third, whatever the dimension we are traveling, the dividing line between rules and standards on the continuum is certainly not a clean one. Standards and rules can even hop over the dividing line, with standards becoming rules through the doctrine of precedent, and rules becoming standards by the creation of exceptions. ${ }^{36}$ Because there is no clarity about rules and standards, the distinction, as represented by the following, will never be fully informative: ${ }^{37}$

\begin{tabular}{|c|c|c|c|}
\hline ire Rule & & & Pure Standard \\
\hline $\begin{array}{l}\text { Specified Facts } \\
\text { Are Determinative }\end{array}$ & $\begin{array}{l}\text { Primary Rule } \\
\text { Has Exceptions }\end{array}$ & $\begin{array}{l}\text { Facts Relevant But } \\
\text { Not Determinative }\end{array}$ & $\begin{array}{l}\text { No Specified } \\
\text { Relevant Facts }\end{array}$ \\
\hline
\end{tabular}

Fourth, and more troubling, the key characteristics of rules and of standards, the ones that would seem to relate to definition, are inconstant. That is, some laws classified as a rule can be quite standard-like in operation, and vice versa. A rule might not pin down the law-applier at all, while a standard could corral the law-applier quite effectively. For example, power, or minimum contacts,

32 See Schlag, supra note 4, at 380 ("It follows that much of legal discourse (including the very fanciest law-talk) might be nothing more than the unilluminating invocation of 'canned' pro and con arguments about rules and standards.").

33 See Korobkin, supra note 7, at 23 ("Rules state a determinate legal result that follows from one or more triggering facts. . . . Standards, in contrast, require legal decision makers to apply a background principle or set of principles to a particularized set of facts in order to reach a legal conclusion."); cf. Nance, supra note 11, at 1295-96 (same, but admitting that a standard may be expressed in a way that looks like a rule, and vice versa).

34 See Eyal Zamir \& Doron Teichman, Behavioral Law AND ECONOMics 556-59 (2018).

35 See Korobkin, supra note 7, at 26 ("the two types of legal forms are better understood, as a descriptive matter, as endpoints of a spectrum"); Nance, supra note 11, at 1296-97.

36 See Nance, supra note 11, at 1297.

37 The diagram comes from Korobkin, supra note 7, at 29. 
exists for specific jurisdiction ${ }^{38}$ if state-directed acts are (a) closely enough "related" to the claim ${ }^{39}$ and (b) substantial enough to constitute "purposeful availment." 40 Although this is a rule in formrelatedness + purposeful availment $=$ power-it is about as subjective as provisions come. ${ }^{41}$ For a contrary example, think of the "when justice so requires" test for amendment of the pleadings under Federal Rule 15(a)(2). ${ }^{42}$ In practice early in the litigation, this standard works like a rule because the law-applier routinely allows a prompt amendment, in order to avoid reversal. Indeed, very early on in the litigation, Federal Rule 15(a)(1) actually converts the amendment standard into a determinate rule, granting the right to amend "as a matter of course." 43

Fifth, and more forgivably, the rule/standard distinction fails to capture completely all the variables that should inform the choice of form. Rule/standard also gives no practical handle on how to formulate the law. Instead, this classification can yield only a feeling about what the law came up with.

Nonetheless, a distinction in terms of vagueness can be a useful and illuminating one. Even if the difference between rule and standard itself turns out to be vague, this "distinction" is useful as an evocative image, one that addresses the question of how much the law pins things down. And a very good question to ask in applying law is whether the law-giver tried to pin things down.

Rule/standard would be more useful if it were more expressly focused on the question of whether the law-giver was trying to pin things down. A vague focus on vagueness does not directly answer the question. Rule/standard would be even more useful if it had helped the law-giver to think about doing so. Jurisprudence should focus on the tool kit of methods available to pin things down. Therefore, I propose a classification on these bases that can still provide the evocative image.

\section{Binary Directives V. SCALAR Directives}

I want to propose a better top-level distinction among the forms of decisional law. The apparent challenge is that although all decisional law can be restated as "if conditions, then consequence," the actual form of the relationship among the directive's conditions is virtually unlimited in theory. That is, you could have something like "if proposition $\mathrm{p}$ implies proposition q, then the consequence $r$ ensues." However, I know of no such directive in decisional law. So far, all directives come in one of two forms:

$$
\text { if } \mathrm{p} \text { is true and/or..., then } \mathrm{r} \text {, }
$$

38 For general jurisdiction, the Court has been more successful in moving from International Shoe's standard of minimum contacts to a rule. See Daimler AG v. Bauman, 571 U.S. 117 (2014) (authorizing usual general jurisdiction over corporations only at the place of incorporation and at the worldwide principal place of business); $c f$. Linda J. Silberman, The Continuing Relevance of Private International Law and Its Challenges: Judicial Jurisdiction and Forum Access-The Search for Predictable Rules 2, 54-55 (NYU School of Law, Public Law Research Paper No. 19-02, Jan. 8, 2019), https://ssrn.com/abstract=3312437 (arguing that recent Supreme Court cases on general and specific jurisdiction mark a move from standards toward predictable rules).

39 See Bristol-Myers Squibb Co. v. Superior Court, 137 S. Ct. 1773 (2017). The Court declined to pin down the required relation. It just said that in order for a state court to exercise specific jurisdiction, the claim must relate to the forum through the defendant's contacts with the forum. "When there is no such connection, specific jurisdiction is lacking regardless of the extent of a defendant's unconnected activities in the State." Id. at 1781.

40 See Clermont, supra note 18, at 273, 285-86. Power for specific jurisdiction will exist for related claims as long as the activity is above some pretty low level. The defendant must have performed acts directed to the forum state with a purpose to avail itself of "the benefits and protection of the laws of that state." Int'l Shoe Co. v. Washington, 326 U.S. 310,319 (1945). This so-called purposeful availment seems to work as a sort of tacit submission to foreseeable jurisdiction that is fair for the defendant.

41 "Subjective" herein means a decision based on personal perspective, and thus inevitably entailing personal feelings and opinions. See Subjective and Objective, http://www.indiana.edu/ p1013447/dictionary/subjobj.htm.

${ }^{42}$ FED. R. CIV. P. 15(a)(2) ("The court should freely give leave when justice so requires.").

${ }^{43}$ FED. R. CIV. P. 15(a)(1) ("A party may amend its pleading once as a matter of course within: (A) 21 days after serving it ....’). 
or

$$
\text { if } \mathrm{p} \text { suffices, perhaps in relation to other considerations ..., then } \mathrm{r} \text {, }
$$

where $\mathrm{p}$ is, respectively, a determinative element or a relevant consideration whose magnitude matters. Both forms reflect the allocation of the burden of persuasion and can accommodate any standard of proof.

The distinction between the two forms is whether the proposition $\mathrm{p}$ is binary or scalar. Binary propositions are those that are true or false, yes or no, 0 or 1 . Scalar propositions can take intermediate values, which represent a statement in some multivalent metric. ${ }^{44}$ The two words are not mere adjectives. The distinction between binary and scalar is a very important distinction. Binary and scalar comprise the two basic ways in which law expresses measurements. ${ }^{45}$

Binary and scalar also mark the divide between the two dominant logical systems: classical bivalent logic and modern multivalent logic. ${ }^{46} \mathrm{~A}$ set for which instances fall either in the set or outside the set, bivalent logicians would call a crisp set. But a set with instances that can be partly in and partly out, multivalent logicians would call a fuzzy, or indefinite, set. I propose to use "crisp" as a synonym of binary, and "indefinite" as a synonym of scalar. Imagine (a) the crisp set of all men from five to seven feet tall for which the measure is that the individual is in or out, and then contrast it with (b) the indefinite set of men somewhere near six feet tall in which the measure can vary from 0 to $1:{ }^{47}$

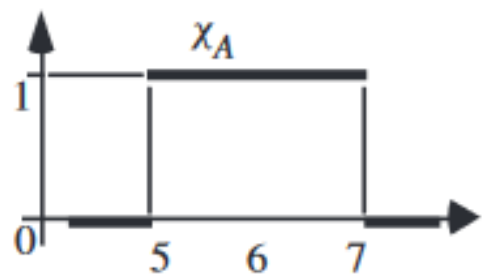

(a)

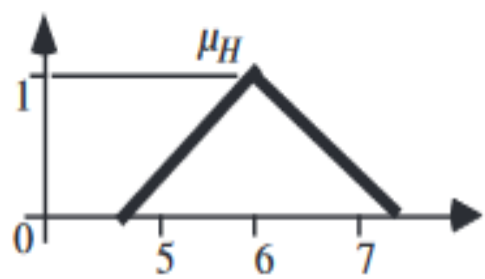

(b)

The former, but not the latter, could be a crisp or binary condition. If a legal directive comprises a checklist of one or more binary conditions, then it is a crisp or binary directive. If instead the directive calls for consideration of scalar measures, it is an indefinite or scalar directive. ${ }^{48}$

Once the factual conditions are found to exist, the application of a binary directive is usually easy. Application is presumptively to be objective and rigid. By contrast, a scalar directive passes the

${ }^{44}$ Gustave Flaubert to Louise Colet, Dec. 11, 1846: « Nier l'existence des sentiments tièdes parce qu'ils sont tièdes, c'est nier le soleil tant qu'il n'est pas à midi. La vérité est tout autant dans les demi-teintes que dans les tons tranchés. »GUSTAVE FLAUBERT, CORRESPONDANCE: PREMIÈRE SÉRIE (1830-1846), at 417 (1926) (“To deny the existence of lukewarm sentiments because they are lukewarm is to deny the sun when it is not at noon. Truth lies as much in its shadings as it does in vivid tones.").

45 See Lawrence Solum, Legal Theory Lexicon: Scalars \& Binaries, http://lsolum.typepad.com/legaltheory/2018/10/legal-theory-lexicon-scalars-binaries.html (mixing conditions and consequences together); cf. Larry Alexander, Scalar Properties, Binary Judgments, 25 J. APPLIED PHIL. 85 (questioning binary moral judgments that turn on scalar properties).

46 See Kevin M. Clermont, Conjunction of Evidence and Multivalent Logic, in LAW AND THE NEW LOGICS 32, 36-48 (H. Patrick Glenn \& Lionel D. Smith eds., 2017) (describing the difference).

47 The figure comes from Timothy J. Ross \& W. Jerry Parkinson, Furzy Set Theory, Furzy Logic, and Fuzzy Systems, in FUZZY LOGIC AND PROBABILITY APpliCATIONS 29, 30 (Timothy J. Ross et al. eds., 2002).

48 If the directive rests on a unidimensional scalar with an ascertainable cutoff, the scalar will serve as a binary condition. See infra text accompanying note 52 . 
real decision to the law-applier. It conveys the message of a discretionary "may" to the law-applier, rather than "must." 49

However, findings as to binary conditions are by no means guaranteed to be easy. To the degree that the law-giver's chosen conditions are not really crisp, the factfinding task will be challenging. First, even seemingly crisp facts involve uncertainty. At the level of natural language, all concepts are somewhat vague. ${ }^{50}$ Second, an indefinite measure always lies behind otherwise crisp facts. The "standard of decision," which attaches to every legal decision, specifies the required measure of sureness, measured in degrees of belief, for reaching any decision. ${ }^{51}$ Third, a crisp proposition might rest on a scalar measure. If it rests on a scalar measure that is a unidimensional value rather than a vector and that has a readily ascertainable cutoff, the proposition can still serve as a condition of a crisp directive. A speed limit of $70 \mathrm{mph}$ is thus a crisp directive, because the determination of speeding is still intended as a yes-or-no issue based on that single, unidimensional, objective measurement, of which the law-applier can make fast work thanks to a speedometer or radar gun: if speed exceeds 70 mph, then guilty. ${ }^{52}$ In sum, all crisp conditions are to a degree scalar.

The defining feature of a binary directive, then, is not how a condition is found to exist, or how easily, but rather whether all the conditions are supposed to be addressed as yes/no issues. A binary directive is a legal test whose conditions ( $p$, etc.) comprise a series of yes/no requirements, because the law-giver implicitly either saw all the conditions as bivalent rather than multivalent or at least wanted them to be treated as if bivalent rather than multivalent.

If there are multidimensional or subjective scalar measures involved in determining whether a condition exists, they cannot be viewed as ending in a yes/no determination. It is an indefinite condition. If any condition is indefinite, the overall directive will be indefinite. The measures can be called "factors," not in the sense of the inputs for some balancing technique, but in the accepted sense of an "influence" on a decision. The factors must be considered in relation to one another. Incidentally, factors can be explicitly or implicitly scalar. And a multitude of measures can be conveyed by a single word; for example, a speed limit prohibiting unreasonable speeds would form an indefinite directive.

\section{A. Advantages}

The distinction is between binary directives that turn on a checklist of solely yes/no facts and scalar directives that entail scaled factors most often considered in connection with other factors. Even if binary/scalar does not determine how much work is left to the law-applier, it tells you what kind of work is left for the law-applier and hence gives a sense of how much freedom is left to it.

Binary directives would often be currently classified as rules, but not always. A formally binary condition might require a subjective, difficult call by the law-applier. Similarly, scalar directives would usually be standards. But a balancing test of a few objective scalar measurements might be very rulelike. Because binary/scalar at least correlates with the rule/standard attributes, the former shares the latter's advantages as an evocative image. For example, binary directives are usually of easy, predictable, certain, and consistent application, and so they work to constrain the law-applier. By contrast, scalar directives usually shift most of the decisional work to the law-applier.

49 See Bengt Lindell, Multi-Criteria Analysis in Legal Reasoning 19 (2017) ("That the court [in a procedural matter] 'may' do something usually means that there is a balancing of interests.").

50 See Bertrand Russell, Vagueness, 1 Australasian J. Psychol. \& PHIL. 84 (1923); see also Bertrand Russell, The Philosophy of Logical Atomism, in LOGIC AND KNOwLEDGE 175, 180 (Robert Charles Marsh ed., 1956) ("Everything is vague to a degree you do not realize till you have tried to make it precise, and everything precise is so remote from everything that we normally think, that you cannot for a moment suppose that is what we really mean when we say what we think."). But cf., e.g., Timothy Williamson, Vagueness (1996); Hartry Field, No Fact of the Matter, 81 Australasian J. PHIL. 457 (2003) (countering the Williamson view).

51 See generally KEVIn M. CleRMOnt, StANDARDs of DECISION IN LAW: PsyCHOLOGICAL AND LOGICAL BASES FOR THE STANDARD OF PROOF, HERE AND ABROAD (2013).

52 The common invocation of a speed limit as the archetypical "rule," e.g., Kaplow, supra note 22, at 560; Korobkin, supra note 7, at 23; Nance, supra note 11, at 1300, encourages me to extend beyond procedural examples and supports the wisdom of classifying the speed limit as a crisp directive. See also infra Part II.D (treating combination of directives). 
Still, binary/scalar is a distinction superior to rule/standard as currently conceived. First, there is a clean distinction between binary and scalar. It turns on whether or not the conditions were viewed as yes/no. Second, binary/scalar is a telling distinction that represents a real difference in the components of law. Binary and scalar measures mark a basic divide. Third, we want to know if the law-giver tried to pin things down. In applying law, we should ask whether the law-giver used binary terms or scalar terms. Fourth, binary/scalar conveys a better sense of the tools at hand for the lawgiver's pinning down the law-applier. It thus enables the tools' deployment in an optimal way. Fifth, it allows the drawing of meaningful subdivisions of binary and of scalar, which bring to the fore the choices in shaping that law, as will be shown below.

Binary/scalar evokes most of the same feelings evoked by the current rule/standard distinction, but it is analytically stronger. It allows us to drill down on how well the law-giver can pin down, or has pinned down, the law-applier.

\section{B. Binary Directives}

The notion of binary directives is readily conveyed by the phrase "elemental decisionmaking." For example, a cause of action will succeed if each of its elements is found to exist. To be a binary directive, the law-giver must have been thinking that the conditions would be addressed as yes/no issues. As to the consequence, it is necessarily yes/no, or dichotomous. ${ }^{53}$

Prime Example of Binary Directive: temporary restraining order. A temporary restraining order, or "TRO," is provisional injunctive relief that is of very short duration, with the judge acting without a hearing and sometimes even without advance notice to the defendant. As to the TRO's terms, the order is typically a stopgap, "to preserve the status quo" and so preserve the capacity to give final relief. ${ }^{54}$ It is given in expectation of a preliminary injunction, which differs in that it comes only after a hearing. ${ }^{55}$

As to the test for getting a TRO, the plaintiff must make a showing of immediate and irreparable harm. ${ }^{56}$ The law-giver has tried to keep the test simple and crisp, in recognition of the inadequate procedure for airing the facts.

The judge, of course, will not often find this test to be crisp. In all likelihood, moreover, the judge will be influenced by a sense of the merits and the balance of harms to the parties and the public. A binary directive just will not work here. So, a bare reference to "immediate irreparable injury" represents little more than hope for a rock in a sea of indefiniteness. Or it represents only a necessary condition, with the court in its discretion able to take those other factors into account. ${ }^{57}$ The end result in practice is a scalar directive that does not differ much from the test for a preliminary injunction. ${ }^{58}$

53 See infra text accompanying note 84 (discussing nondichotomous consequences).

54 11A Charles Alan Wright, Arthur R. Miller \& Mary Kay Kane, Federal Practice and Procedure $\$$ 2951, at 274 (3d ed. 2013); see id. at 279 (discussing the aim to preserve availability of final relief). But see id. at 291 (acknowledging that rarely affirmative relief is possible, citing United States v. George, 239 F. Supp. 752 (D. Conn. 1965 ) (allowing hospital to administer blood transfusion)).

55 See id. \$ 2947, at 116-17 (distinguishing the two remedies).

56 See id. \$ 2951, at 274, 278-79 (phrasing the requirement as "the possibility that irreparable injury will occur before the hearing for a preliminary injunction" and reiterating the need for immediate relief); $c f$. FED. R. CIV. P. 65(b)(1)(A) (providing that an ex parte TRO requires facts "clearly show [ing] that immediate and irreparable injury, loss, or damage will result to the movant before the adverse party can be heard in opposition").

57 See 11A WRIGHT ET AL., supra note 54, \2951, at 294 ("There are several factors in addition to irreparable injury that usually are considered by the court in exercising this discretion," mentioning probability of success, the balance of hardships, and the public interests.).

58 See, e.g., McKenzie v. Option One Mortgage, 321 F. Supp. 3d 186, 188 (D. Mass. 2018) ("In evaluating a motion for a TRO, the Court considers the same four factors that apply to a motion for preliminary injunction, that is: the likelihood the movant will succeed on the merits, whether the movant is likely to suffer irreparable harm in the absence preliminary relief, the balance of equities, and whether an injunction is in the public interest.”); Terra Int'l, Inc. v. Miss. Chem. Corp., 896 F. Supp. 1468, 1473 \& n.8 (N.D. Iowa 1995) (“Ordinarily, the grant or denial of a temporary restraining 


\section{Necessary v. Sufficient}

One might think that a useful subdivision of binary directives would be between necessary elements and sufficient conditions. Necessary elements would be those joined by the conjunction "and." Only if all the elements are found would the specified consequence follow. By contrast, a sufficient condition would be one joined by "or." An example could be constructed from several affirmative defenses.

However, this subdivision is of illusory significance. Any set of necessary elements can be viewed as a sufficient way to get to a specified consequence that is reachable by some alternative route. One tends to use the terminology of sufficient conditions whenever the alternative routes to a decision are obvious. Without subdividing, we can simply use condition to mean a necessary or sufficient finding that tends to allow a claim or defense to succeed under the substantive law. ${ }^{59}$

\section{Hard v. Soft}

A better subdivision would be between hard and soft degrees of crispness. Again, there are binary directives that are hard (bright-line, like a speed limit of $70 \mathrm{mph}$ ) and scalar directives that are soft (vague, like a speed limit prohibiting unreasonable speeds). But such a spectrum exists among binary directives alone. Some binary directives have all conditions being truly crisp, and others have one or more conditions being spongy. On the one hand, requiring a process server to be "at least 18 years old and not a party" is pretty crisp. ${ }^{60}$ On the other hand, designating a counterclaim as compulsory if it arises from the same "transaction or occurrence" is pretty vague. ${ }^{61}$ If the rulemakers nevertheless meant "transaction or occurrence" as a binary determination, the transactional requirement would be a condition in a binary directive; if, however, they meant to delegate the transactional decision to future law-appliers by calling for a consideration of various scalar factors, "transaction or occurrence" would form a scalar directive that guides how to decide.

In general, softly crisp directives are to be avoided. ${ }^{62}$ Such directives erode the clean distinction between binary and scalar. If any condition does not really possess an on/off nature, it is preferable

order or preliminary injunction in this circuit is determined upon consideration of the factors stated in Dataphase Sys., Inc. v. CL Sys., Inc., 640 F.2d 109, 113 (8th Cir. 1981) (en banc)," which held, "Those standards require that a preliminary injunction or TRO issue only after consideration of the following factors: (1) the threat of irreparable harm to the movant; (2) the state of the balance between this harm and the injury that granting the injunction will inflict on other parties involved in the litigation; (3) the probability that the movant will succeed on the merits; and (4) the public interest."). Some authorities suggest that the standard of proof is elevated to reflect the remedy's emergency and drastic nature and its more truncated procedure. See, e.g., Free Country Ltd v. Drennen, 235 F. Supp. 3d 559, 565 (S.D.N.Y. 2016) (“The standard for an entry of a TRO is essentially the same as for a preliminary injunction. . . Therefore, a TRO, perhaps even more so than a preliminary injunction, is an 'extraordinary and drastic remedy, one that should not be granted unless the movant, by a clear showing, carries the burden of persuasion.”' (quoting JBR, Inc. v. Keurig Green Mountain, Inc., 618 F. App'x

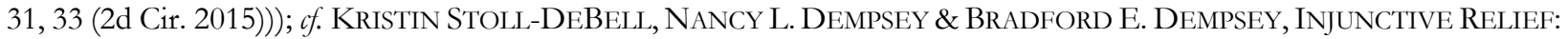
TEMPORARY RESTRAINING ORDERS AND PRELIMINARY INJUNCTIONS 150 (2009) (saying that TROs "tend to be more difficult to obtain"). Elevating the standard of proof for TRO, which issues without a hearing, would make good sense. But courts also mention a "clear showing" being required for a preliminary injunction. See 11A WRIGHT ET AL., supra note 54, \ 2948, at 119-21. Thus, this particular "clear showing" standard of proof for provisional injunctive relief seems more a rhetorical flourish than an actual requirement. See id. at 121-22 ("Although these shorthand formulations aptly express the courts' general reluctance to impose an interim restraint on defendant before the parties' rights have been adjudicated, they do not take the place of a sound evaluation of the factors relevant to granting relief under Rule 65(a).').

59 See Michael R. Smith, Elements v. Factors (pts. 1 \& 2), WYO. LAW., Apr. 2016, at 46, Aug. 2016, at 50.

60 See FED. R. CIV. P. 4(c)(2).

61 See FED. R. CIV. P. 13(a)(1)(A); FIELD ET AL., supra note 5, at 70-75; Douglas D. McFarland, In Search of the Transaction or Occurrence: Counterclaims, 40 CREIGHTON L. REV. 699 (2007); cf. Douglas D. McFarland, Seeing the Forest for the Trees: The Transaction or Occurrence and the Claim Interlock Civil Procedure, 12 FLA. COASTAL L. REV. 247 (2011) (generalizing his treatment).

62 See ALEXANDER \& SHERWIN, supra note 30, at 33 ("If the rules did this-if, in other words, the rules were really standards - then they could not settle the very questions they were meant to settle.”). 
to state the directive as an honestly scalar one. Stating it in the form of a binary directive can only mislead. Whether stated as a binary directive or a scalar one, it will be the law-applier who does the real work of decision. Using a binary form will not constrain the law-applier. By explicitly embracing indefiniteness, the law-giver will be better able to constrain the law-applier in appropriate ways, as I shall now explain.

\section{Scalar Directives}

The notion of scalar directives is readily conveyed by the phrase "factorial decisionmaking." An example comes by switching focus from the power test for personal jurisdiction to its reasonableness test, an additional test whereby the court must consider these factors:

Implicit in this emphasis on reasonableness is the understanding that the burden on the defendant, while always a primary concern, will in an appropriate case be considered in light of other relevant factors, including the forum State's interest in adjudicating the dispute; the plaintiff's interest in obtaining convenient and effective relief, at least when that interest is not adequately protected by the plaintiff's power to choose the forum; the interstate judicial system's interest in obtaining the most efficient resolution of controversies; and the shared interest of the several States in furthering fundamental substantive social policies. ${ }^{63}$

The characteristic feature of these factors is that the law-giver was not thinking that the conditions would be addressed as yes/no issues, but instead would be evaluated on a scale and then somehow integrated. "Reasonableness" might sound like a yes/no issue, but in any realistic sense it is only suggesting a range of considerations. The law-giver's contribution thus is a guide for decision, one that ensures putting some scope of considerations before the law-applier.

In any scalar directive, the factors are relatively free-form, discretionary, and subjective, if compared to a determinative element. The nature of the factors to be considered varies widely. They can involve assessment of values, principles, policies, and objectives. Or they can be more concrete. Examples include probabilities of future events, dollars in estimating harm as damages, and expected cost. The last of these examples involves the multiplication of probabilities and dollars, and so makes the point that some operations, such as multiplication, can be necessary to evaluate the factor.

To reach a decision, the law-applier must decide the degree to which each factor is present. The law-applier must then consider all factors in relation to each other. Some factors will compensate for the weakness of others, and some factors will undercut others. Here is another source of the lawapplier's robust discretion, which is the key feature of a scalar directive. The law-applier has real "choosing" power.

Prime Example of Scalar Directive: preliminary injunction. After notice and hearing, the court may grant a motion for a preliminary injunction, which can last until final judgment. ${ }^{64}$ The remedy is discretionary. ${ }^{65} \mathrm{It}$ is said that "a district court must have considerable discretion because of the infinite variety of situations which may confront it." The leading treatise states the purpose of the remedy thus:

Although the fundamental fairness of preventing irremediable harm to a party is an important factor on a preliminary-injunction application, the most compelling reason in favor of entering a Rule 65(a) order is the need to prevent the judicial process from being rendered futile by defendant's action or refusal to act. On the other hand, judicial intervention before the merits have been finally determined may impose a burden on defendant that ultimately turns out to have been unjustified. Consequently, the preliminary injunction is appropriate whenever the policy of preserving the court's

${ }^{63}$ World-Wide Volkswagen Corp. v. Woodson, 444 U.S. 286, 292 (1980) (citations omitted).

64 See 11A WRIGHT ET AL., supra note 54, \$ 2947.

65 See Trump v. Int'l Refugee Assistance Project, 137 S. Ct. 2080, 2087 (2017) (“Crafting a preliminary injunction is an exercise of discretion and judgment, often dependent as much on the equities of a given case as the substance of the legal issues it presents.").

${ }^{66}$ A.L.K. Corp. v. Columbia Pictures Indus., Inc., 440 F.2d 761, 763 (3d Cir. 1971). 
power to decide the case effectively outweighs the risk of imposing an interim restraint before it has done so. ${ }^{67}$

By clarifying the purpose and then drafting a test tightly focused on that purpose, "a court's discretion will be bounded by the attributes of the standard itself." 68

In the very old days the judge's discretion was largely unconstrained, except by various soon-obsolete restrictions tied to the jurisdiction of and comity between courts. ${ }^{69}$ By the nineteenth century various modern themes of constraint started to emerge, most often tied to the balance of harms and the plaintiff's likelihood of success. ${ }^{70}$ Today, courts pursue an optimally constrained flexibility by a "dizzying diversity of formulations." 71 The dominant approach is a four-factor test that asks the court (1) whether the plaintiff will be irreparably harmed if the preliminary injunction is denied, (2) whether the harm to the plaintiff if the preliminary injunction is denied will exceed the harm to the defendant if it is granted, (3) whether the plaintiff is reasonably likely to prevail at trial, and (4) whether the public interests will be affected by granting or denying the injunction. ${ }^{72}$

Some courts require the plaintiff "to carry the heavy burden of proving all four factors .... In this form, the standard is called the traditional or sequential test." ${ }^{73}$ That is, these courts hold onto the hope of preserving a binary directive, despite the hopelessness owing to the great uncertainty about what each of the four factors means. ${ }^{74}$ Consequently, these courts are too stingy in granting preliminary injunctions. ${ }^{75}$

67 11A WRIGHT ET AL., supra note 54, S 2947, at 114 (footnote omitted).

${ }^{68}$ Lea B. Vaughn, A Need for Clarity: Toward a New Standard for Preliminary Injunctions, 68 OR. L. REV. 839, 842 (1989); see R. Grant Hammond, Interlocutory Injunctions: Time for a New Model, 30 U. Tor. L.J. 240, 272 (1980) ("A discretionary formula, though fashionable, raises the dangers of potential judicial arbitrariness with respect to a remedy which is often dispositive of litigation and the difficulties of mounting an appeal from a discretion.").

69 See John Leubsdorf, The Standard for Preliminary Injunctions, 91 HARV. L. REV. 525, 527-32 (1978).

70 See id. at 532-40.

71 Id. at 526; see Morton Denlow, The Motion for a Preliminary Injunction: Time for a Uniform Federal Standard, 22 REV. LITIG. 495, 507-30, 538-39 (2003) (arguing for a three-factor sequential test); Vaughn, supra note 68, at 840-42 (arguing for a sliding-scale test); Arthur D. Wolf, Preliminary Injunctions: The Varying Standards, 7 W. NEW ENG. L. REV. 173, 183, 235-36 (1984) (arguing, after observing that "the federal appellate courts use at least nine different tests," for a five-step approach closely related to nineteenth-century practice); see also Michael T. Morley, Beyond the Elements: Erie and the Standards for Preliminary and Permanent Injunctions, 52 AKRON L. REV. (forthcoming 2018), available at https://ssrn.com/abstract=3272546 (extending the variations to the Erie setting); David E. Shipley, The Preliminary Injunction Standard in Diversity: A Typical Unguided Erie Choice, 50 GA. L. REV. 1169 (2017) (favoring application of federal law); Arthur D. Wolf, Preliminary Injunction Standards in Massachusetts State and Federal Courts, 35 W. NEW ENG. L. REV. 1, 23 \& n.6 (2013) (raising the problem of reverse-Erie's possible call for federal law applying in state court); cf. Hammond, supra note 68, at 281 (arguing, after surveying Anglo-American law, for a test that would serve the purpose of "preservation of litigation for an effective later decision"). For more on the comparative front, see TORSTEN FRANK KOSCHINKA \& Piero LeAnZa, Preliminary Injunctions: Germany, ENGLAND/WALES, ITALy AND FranCE (2015).

72 See, e.g., Winter v. Nat. Res. Def. Council, Inc., 555 U.S. 7, 20 (2008) (“A plaintiff seeking a preliminary injunction must establish that he is likely to succeed on the merits, that he is likely to suffer irreparable harm in the absence of preliminary relief, that the balance of equities tips in his favor, and that an injunction is in the public interest."); $11 \mathrm{~A}$ WRIGHT ET AL., supra note 54, \ 2948, at 122-24. Some courts list other factors. See, e.g., Lawson Products, Inc. v. Avnet, Inc., 782 F.2d 1429, 1433, 1441 (7th Cir. 1986) (mentioning a fifth factor: "no adequate remedy at law"). But these additional "factors" seem to be independent requirements expressing the idea that preliminary injunctions are subject to the usual restrictions on equitable relief, although some of those restrictions might already be implicit in the four factors. See 11A WRIGHT ET AL., supra note 54, \ 2948.1, at 129 (saying that irreparable harm cannot usually be shown "if it appears that the applicant has an adequate alternative remedy"); infra note 100.

73 Vaughn, supra note 68, at 840.

74 See 11A WRIGHT ET AL., supra note 54, SS 2948.1-.4.

75 See Taylor Payne, Now Is the Winter of Ginsburg's Dissent: Unifying the Circuit Split as to Preliminary Injunctions and Establishing a Sliding Scale Test, 13 TENN. J. L. \& POL'Y 15, 47-50 (2018). 
A more progressive approach calls on the court instead to apply the four-factor test as a sliding-scale test. The court will somehow combine those four factors, granting or denying provisional relief in a more or less rigorous attempt to choose the superior path. ${ }^{76}$ That is, granting this discretionary remedy to minimize wrongful harm will involve measuring the tilt toward interim relief in the balance of the plaintiff's and the defendant's harms and the public interests, with the required degree of tilt decreasing as the likelihood of the plaintiff's ultimate success on the merits increases. ${ }^{77}$ On the one hand, the incredible range of free play in such a scalar directive helps explain the preliminary injunction's dark history of misuse against labor unions and civil rights activists. ${ }^{78}$ On the other hand, common sense calls for the balancing of factors, as it is obvious, for an example, that a plaintiff who is almost certain to win should be allowed to get by with a lesser showing on the balance of harms. In any event, although both the sequential and the sliding-scale tests might be "standards," they are fundamentally different, in that one is a failed attempt at crispness and the other is a fervent embrace of indefiniteness.

Many other examples could be listed. ${ }^{79}$ They might employ different scales. The scale in use will affect the form of the decisional law. The varying nature of the scale in use could even generate subdivisions of scalar directives, but so subdividing would yield few insights. There are, however, many other possible bases for subdividing, and some are quite instructive.

\section{Hard v. Soft}

Like rules, standards, and binary directives, the range of scalar directives extends from relatively hard (e.g., minimize the sum of two specified costs) to very soft (e.g., act in the interests of justice). Similarly, the factors could be subclassified as objective or subjective. An objective factor could even be mechanically measurable, such as speed. By contrast, "unreasonably cumulative" discovery calls for a very subjective judgment.

One could roughly place a scalar directive somewhere on either of these continua, but the subdividing effort would not be as informative as making some other possible distinctions listed below, which the hard-to-soft or objective-to-subjective continuum would mask. The reason is that most scalar directives already have a lot of flexibility, and so these distinctions would not add much classification value.

\section{Additive v. Nonadditive}

76 See Vaughn, supra note 68, at 840.

77 See, e.g., Abbott Lab. v. Mead Johnson \& Co., 971 F.2d 6, 11-12 (7th Cir. 1992) (applying this sliding-scale approach).

78 See Walker v. City of Birmingham, 388 U.S. 307 (1967) (jailing Martin Luther King, Jr.); CQ Researcher, The Use of Injunctions in Labor Disputes, https:/ / library.cqpress.com/cqresearcher/document.php?id=cqresrre1928020400 ("The basic objection raised against the injunction when it first came into wide use in labor disputes was that it was an instrument of the rich for suppressing the legitimate efforts of the poor ....").

${ }^{79}$ The question on a stay is the same as the question on a preliminary injunction. See Nken v. Holder, 556 U.S. 418 , 426 (2009) (“'A] court considers four factors: '(1) whether the stay applicant has made a strong showing that he is likely to succeed on the merits; (2) whether the applicant will be irreparably injured absent a stay; (3) whether issuance of the stay will substantially injure the other parties interested in the proceeding; and (4) where the public interest lies."' (quoting Hilton v. Braunskill, 481 U.S. 770, 776 (1987))); Cavel Int’l, Inc. v. Madigan, 500 F.3d 544, 546-47 (7th Cir. 2007) (Posner, J.) (ruling that the same test applies to stays as to preliminary injunctions: "It amounts simply to weighting harm to a party by the merit of his case."). But some mistakenly argue that a stay poses a different question. E.g., Jill Wieber Lens, Stays of Injunctive Relief Pending Appeal: Why the Merits Should Not Matter, 43 FLA. ST. U. L. REV. 1319, 1358 (2016) (focusing only on "whether circumstances could change in a way that would render the appellate court unable to issue a decision meaningful to the parties, how the parties might be harmed by the relief, or lack thereof, and the public interest"); Portia Pedro, Stays, 106 CALIF. L. REV. 869 (2018) (arguing that the purpose of a stay pending appeal is to protect a meaningful opportunity to appeal where guaranteed); cf. infra note 103 (observing similar vacillation on the purpose of a preliminary injunction). 
The factors in a scalar directive are multivalent. That is, they are not only true or false, but can take any value on the scale. Further, they might be simply multivalent or they could actually be fuzzy. ${ }^{80}$

By simply multivalent, I mean scalar measures that are still additive. In an additive system, a set and its complement add to the universe, or one. Thus, the probability that an event will happen and the probability that it will not happen add to one.

Contrastingly, in the fuzzy world, a set can overlap its complement, which means that additivity does not prevail. Hence, nonadditive fuzzy measures are subject to fuzzy multivalent logic rather than classical binary logic. An example here is fuzzy degrees of belief and disbelief in a fact, where the factfinder retains some belief as uncommitted between true and false, so that belief and disbelief do not add to one.

For some purposes, this distinction could be an important difference. Fuzzy calculations would follow a different logical system than, say, probabilities that ultimately assume bivalence. Measuring the fuzzy factor's size would thus call for the application of fuzzy logic's distinctive logical operators when performing such operations as conjunction or disjunction. ${ }^{81}$ However, in the final step of deducing the consequence from the fuzzy factors, the presence of fuzzy factors would present no complications, because each of those factors would have undergone the step of defuzzification to produce a usual scalar measure. ${ }^{82}$

\section{Dichotomous v. Nondichotomous}

As a matter of form, we can also subclassify scalar directives by their consequence. ${ }^{83}$ Outputs can be yes/no or can be selected among multiple choices. ${ }^{84} \mathrm{I}$ am speaking of dichotomous or nondichotomous consequences here, as opposed to the binary or nonbinary conditions discussed above.

Most scalar directives have a dichotomous consequence. But a nondichotomous consequence is possible for them, and indeed common in criminal sentences, money damages, or terms of injunctions. For a nondichotomous consequence, the factfinder could sequentially consider the factors with respect to each outcome and choose the optimizing one. Or the factfinder could formulate its best judgment of the conditions' satisfaction by placing its estimate on some commensurable scale. With the latter sort of method, the law could be quite comfortable with a range of consequences. Each possible consequence would correspond to a point on or a part of the scale. Sometimes the law would correlate decisional categories, like the degrees of the crime, to the scale's metric. Sometimes the scale's metric would directly produce the consequence, as is done with money damages.

\section{Exhaustive v. Nonexhaustive}

The list of factors would comprise a number of relevant considerations. The factors listed by the law-giver might constitute the whole list of relevant factors or might merely be suggestive of other feature).

${ }^{80}$ See Clermont, supra note 6, at 6-7 nn.20-22, 29-30 nn.97-100 (distinguishing the terms on the basis of the additivity

81 See id. at 26-35 (rejecting the product rule for fuzzy measures, and instead applying fuzzy logic's MIN and MAX rules for conjunction and disjunction, respectively).

82 See CLERMONT, supra note 51, at 208 ("The law dictates that factfinders decide by subjecting their fuzzy beliefs to a standard of proof in order to come to an unambiguous output. That is, at this point the law forces factfinders back into what looks like a two-valued logic, by forcing them to decide for one party or the other. Such disambiguation is not a practice unique to law. All fuzzy computer programs end with a step that produces an unambiguous output, a step called defurification.").

${ }^{83} \mathrm{I}$ am speaking only of form. There are strong policies entailed in the choice of form. There are many effects of the form chosen. For an example, presenting a range of consequences to the factfinder may psychologically affect the factfinder's performance. See, e.g., Neil Vidmar, Effects of Decision Alternatives on the Verdicts and Social Perceptions of Simulated Jurors, 22 J. PERSONALITY \& SOC. PSYCHOL. 211 (1972) (giving jurors multiple choices of conviction varying in severity decreased the number of acquittals).

84 See Adam J. Kolber, Smooth and Bumpy Laws, 102 CALIF. L. REV. 655, 666-68 (2014) (calling dichotomous consequences bumpy, and nondichotomous consequences smoother). 
factors. That is, they might be exhaustive, in which case the law-giver is saying to the law-applier: consider only these factors, and if the combination is strong enough in your judgment, impose the consequence. Or they might be nonexhaustive, in which case the law-giver is saying to the law-applier: consider these factors along with whatever else you think worth considering in order to render a decision. Obviously, the former puts a greater restraint on the law-applier, and so this subdivision is an important one. ${ }^{85}$

Alternatively, the law-giver could exclude a factor, such as race, from consideration. It would then be saying to the law-applier: do not give any weight to this factor when you weigh whatever else you are considering in order to render a decision.

\section{Nonsystematic v. Systematic}

A scalar directive might just list a bunch of vague factors, even making the list nonexhaustive, and then give no way to combine them or even to make them commensurable. Here the directive puts minimal controls on the law-applier. ${ }^{86}$ In contrast, some exhaustive directives are so systematized as to merit their own label, such as true balancing tests. If such a test is taken seriously, the law-applier will find itself rather boxed in.

Nonsystematized and systematized are not merely adjectives. They signal directives that are different in character. They are worthy of separate treatment. Indeed, experience shows that the best subdivision of scalar directives is between those that are not systematized and those that are systematized.

\section{a. Balancing Tests}

Balancing tests could be defined very broadly, ending up as meaning any scalar directive. Balancing would then mean a method of "identifying interests implicated by the case" and reaching a decision "by explicitly or implicitly assigning values to the identified interests." Balancing tests would thus run the full spectrum from nonsystematized to systematized, that is, from largely unconstraining to somewhat controlling. ${ }^{88}$

I propose instead to define "true balancing tests" as only certain scalar directives, those that are highly systematized and controlling. First, a true balancing test explicitly or implicitly presents an exhaustive listing of factors to be weighed against one another, which would usually be done to choose between dichotomous outcomes. An exhaustive listing could be definitive, although it could instead be exhaustive only in the sense of "all things considered." Second, true balancing implies rough quantification of the factors. Third, the quantification must come in a commensurable measure, so as to allow an attempt at true balancing. I am not suggesting that balancing ties the decider's hands and eliminates deciding by hunch. But having to place even rough estimates of specified factors onto a balance does nudge the judge or other decider toward self-discipline, while giving appellate panels and the public a handle for review.

There remains room for some variety among true balancing tests, in terms of the degree of systematization and in terms of the interests balanced. Any sorts of interests could be balanced, as long as they are expressed in commensurable terms. Thus, state and federal interests are balanced to

85 See ALEXANDER \& SHERWIN, supra note 30, at 30 (exhaustiveness "moves some distance from being a pure standard and toward being a 'rule"').

86 See, e.g., Fisher v. Univ. of Tex. at Austin, 136 S. Ct. 2198, 2207 (2016) ("Therefore, although admissions officers can consider race as a positive feature of a minority student's application, there is no dispute that race is but a 'factor of a factor of a factor' in the holistic-review calculus.").

87 T. Alexander Aleinikoff, Constitutional Law in the Age of Balancing, 96 YALE L.J. 943, 945 (1987) (criticizing balancing in contrast to binary directives); see Wilson, supra note 11, at 773 (defining balancing in contrast to binary directives).

88 See Francisco J. Urbina, A Critique of Proportionality and Balancing 9 (2017) (identifying two accounts of balancing: "One sees [it] as a doctrinal tool aimed at maximising the interests, values, or principles at stake in the case. ... The other account sees [it] as a doctrinal tool that allows judges to engage in open-ended moral reasoning, unconstrained by legal sources."). 
determine the applicable law under Erie. ${ }^{89}$ Moreover, the balance could be weighted in one direction by fixing certain interests on one side of the balance or by heightening the standard of decision. For example, the right to civil counsel rests on procedural due process's cost-benefit balance, but the balance is performed against a presumption that the right exists only if physical liberty is at risk. ${ }^{90}$

One common kind of true balancing test calls for a "balance of equities." It is used, for example, in deciding whether to allow a party to alter its position in litigation, as by amending pleadings, discovery responses, or pretrial orders. For amendment of the pleadings under Federal Rule 15(a)(2), ${ }^{91}$ the equities are seen as fault and harm. It is up to the opponent (O) of the amendment's movant (M) to convince the judge to disallow the amendment by showing a balance of the parties' and public's interests in favor of no amendment. ${ }^{92}$ Because the equities involve a set of offsetting factors that fall on either side of the balance, the amendment's opponent must show:

$$
\text { (M's fault - prejudice to M) > (O’s fault - prejudice to } \mathrm{O}+\text { net public interest), }
$$

where M's fault comes from any delay in moving to amend; the prejudice to M means detriment to a full presentation of the merits that would be unavoidably caused by denying the amendment; O's fault comes from any inducing of the delay; and the prejudice to $\mathrm{O}$ means the disadvantage to reliance interests attributable to the delay that would be unavoidably caused by allowing the amendment. Then the court must throw onto the scales of the balance the considerations of public interest, which usually favor amendment. ${ }^{93}$

Another common kind of true balancing test calls for cost-minimization or, equivalently, costbenefit analysis. ${ }^{94}$ For a first and notable example, the Supreme Court has defined procedural due process to require a procedural safeguard only when the expected harm without the safeguard substantially outweighs the safeguard's cost. ${ }^{95}$ For a second example, courts employ this kind of balancing in deciding whether to give a protective order against discovery. ${ }^{96}$ Third, a request for declaratory judgment is justiciable in "a case of actual controversy." 97 That term sounds like a binary directive. But the courts have not so interpreted it. Instead of the more usual kind of categorical definition, they have adopted a so-called operational definition, which defines in terms of the outcome of a specified process. Here, an actual controversy exists if the private and public benefits of deciding a declaratory judgment suit exceed the private and public costs of deciding. ${ }^{98}$

Prime Example of Balancing Test: injunctive relief. Issuance of a permanent injunction as final relief is quite different from issuing provisional injunctive relief. In reality, the decision on final relief is not so different from other remedial final decisions. First, final injunctive relief depends on the substantive law. That decisional law will consist, as usual, of various binary directives and scalar directives. Second, traditional equitable restrictions on relief would limit final injunctive relief. ${ }^{99}$ Some of these are apparently viewed as binary. An

89 See Erie RR. Co. v. Tompkins, 304 U.S. 64 (1938); ClERMONT, supra note 18, at 206-09.

90 See Lassiter v. Dep't of Soc. Servs., 452 U.S. 18, 26-27 (1981) (describing presumption); infra note 95.

${ }^{91}$ FED. R. CIV. P. 15(a)(2) (“The court should freely give leave when justice so requires."); supra note 42.

92 See LINDELL, supra note 49, at 20 ("Balancing of interests can be triadic.").

93 See FIELD ET AL., supra note 5, at 76-77.

94 See generally CASs R. Sunstein, THE COST-BENEFIT REVOLUTION (2018).

95 See Mathews v. Eldridge, 424 U.S. 319 (1976).

96 See FED. R. CIV. P. 26(c).

9728 U.S.C. $\int 2201$ (a).

98 See CLERMONT, supra note 18, at 149. Similarly, "validity' of a judgment rests on whether the judgment is of sufficient quality to withstand an attack by request for relief from judgment, a process that turns on a balance of equities. See id. 385-88.

99 See Field ET AL., supra note 5, at 1202-08; 1 JAMEs L. High, A TrEATISE ON THE LAW OF INJUNCTIONS $\int S$ 7-33 (Shirley T. High ed., 4th ed. 1905); 11A WRIGHT ET AL., supra note 54, JS 2942-2946. 
example would be the requirement that there be no adequate legal remedy. ${ }^{100}$ Others are unabashedly indefinite. An example would be the discretionary balancing of the parties' and public's interests to decide on whether to issue a final injunction in favor of the prevailing party. ${ }^{101}$ Third, a cost-minimization balancing technique would guide the court in selecting the terms of any injunction, so extending the balancing form to nondichotomous outcomes.

Now, return to the test for provisional injunctive relief. Professor John Leubsdorf has brilliantly argued that the decisional law should further control the judge's discretion by focusing more sharply on the purpose of a preliminary injunction. ${ }^{102} \mathrm{He}$ established that a preliminary injunction's aim is to minimize in the interim the probable irreparable loss of legal rights that would be caused by an erroneous decision reached by the rudimentary procedure for provisional decision. ${ }^{103}$ The right decision would come from comparing the expected costs of wrongful denial with the expected costs of wrongful grant. ${ }^{104}$

His motivating idea is simple. After the court settles on the terms of the potential preliminary injunction by a cost-minimization balancing technique, the issue becomes a dichotomous one: either grant the envisaged preliminary injunction or do not. To minimize costs, the court should compare the expected costs of error on each route and, of course, should take the route that is less costly. A true balancing test could capture the two routes' comparison. The court should grant provisional relief when (1) the expected costs of wrongfully denying it exceed (2) the expected costs of wrongfully granting it. The first factor equals the product of the estimated probability $(P)$ that the plaintiff is in the right, in the sense of winning the case ultimately, ${ }^{105}$ times the unavoidable and irreparable harms $\left(H_{p}\right)$ to the plaintiff's and others' legal rights in the absence of the preliminary injunction, with the substantive law determining which harms to count. ${ }^{106}$ The second factor equals the product

100 See 11A WRIGHT ET AL., supra note 54, \2944, at 85-87 ("The legal remedy may be deemed inadequate if any one of a number of factors is present. .. . Probably the most common method of demonstrating that there is no adequate legal remedy is by showing that plaintiff will suffer irreparable harm if the court does not intervene and prevent the impending injury."); supra note 72.

101 See 11A WRIGHT ET AL., supra note 54, 』 2942, at 40-42, 51-53; Developments in the Law-Injunctions, 78 HARV. L. REV. 994 (1965).

102 Leubsdorf, supra note 69, at 542. His theory was adopted in Packaging Industries Group, Inc. v. Cheney, 405 N.E.2d 106, 11-12 (Mass. 1980), and, more famously, by Judge Posner in American Hospital Supply Corp. v. Hospital Products Ltd., 780 F.2d 589, 594 (7th Cir. 1986). But the Seventh Circuit returned to its four-factor balancing test in Abbott Laboratories v. Mead Johnson \& Co., 971 F.2d 6, 11-12 (7th Cir. 1992).

103 See Leubsdorf, supra note 69, at 540-41. This is the key analytic step. Those sophisticated analysts who disagree with Leubsdorf do so because they see a different purpose for the preliminary injunction. See Richard R.W. Brooks \& Warren F. Schwartz, Legal Uncertainty, Economic Efficiency, and the Preliminary Injunction Doctrine, 58 STAN. L. REV. 381 (2005) (claiming the purpose of the preliminary injunction is to promote efficient conduct during a lawsuit); Vaughn, supra note 68, at 850-51 (claiming the purpose of the preliminary injunction is to "create a state of affairs that will best give effective relief to the parties when the case has been fully heard on the merits"). Leubsdorf wrote a convincing rebuttal of Brooks \& Schwartz in John Leubsdorf, Preliminary Injunctions: In Defense of the Merits, 76 FORDHAM L. REV. 33 (2007), as well as to Vaughan in Leubsdorf, supra note 69, at 545-46.

104 See Leubsdorf, supra note 69, at 542 ("The court, in theory, should assess the probable irreparable loss of rights an injunction would cause by multiplying the probability that the defendant will prevail by the amount of the irreparable loss that the defendant would suffer if enjoined from exercising what turns out to be his legal right. It should then make a similar calculation of the probable irreparable loss of rights to the plaintiff from denying the injunction. Whichever course promises the smaller probable loss should be adopted.").

${ }_{105} \mathrm{P}$ measures the probability of the plaintiff's winning, as calculated on the hastily heard and hence uncertain facts, given the court's view of the law. See Thornburgh v. Am. Coll. of Obstetricians \& Gynecologists, 476 U.S. 747,757 (1986) (discussing standard of review). By using a balancing approach, the judge may avoid the lock-in effect, which biases a judge against neutrally revisiting the merits when the judge has already made a provisional decision. See Kevin J. Lynch, The LockIn Effect of Preliminary Injunctions, 66 FLA. L. REV. 779, 802-03, 809-11 (2014).

${ }_{106}$ Cf. Douglas Lichtman, Uncertainty and the Standard for Preliminary Relief, 70 U. CHI. L. REV. 197, 199 (2003) (arguing that the formula should also take into account the uncertainty in estimating $H$, despite the complications of doing so). 
of the probability that the defendant will win the case times the unavoidable and irreparable harms $\left(H_{d}\right)$ to the defendant's and others' legal rights that would be caused by the preliminary injunction. To put it algebraically, grant the preliminary injunction if and only if:

$$
P H_{p}>(1-P) H_{d}
$$

The formula captures fully the first three of the four factors in the dominant approach to preliminary injunctions. ${ }^{107}$ The fourth factor of public interests enters the formula as well, constituting part of $H_{p}$ or $H_{d}$, but perhaps only insofar as third-party interests are relevant to final decision under the substantive law. ${ }^{108}$

This formula thus serves to help define the four factors. ${ }^{109}$ More importantly, it specifies the relationship among the factors. It thereby works to discipline somewhat the judge's function by specifying the relevant factors and showing how they interact. Imposing this discipline seems preferable to the sometimes lazy, whimsical, or biased-and always hidden-exercise of equitable power. In other words, this formula serves the important purpose of decisional law to reduce the realm of subjective decisionmaking's unobservable black box, even if that realm can never be and arguably should not be completely eliminated. ${ }^{110}$ Courts $^{111}$ and commentators ${ }^{112}$ attack the formula for being, well, a formula. But it does not require numerical analysis. It is just championing rigorous thinking. It identifies all the relevant factors and tells how they interact. ${ }^{113}$ If the formula is correct, then arguing for authority to give a different answer is an argument that equity should liberate the judge to give the wrong answer. Pushing for any approach comprising undefined and unquantifiable factors to be combined in an unspecified way is championing lawlessness, even here where there are no offsetting benefits of an obscure directive. ${ }^{1 / 4}$

True balancing tests are very significant because they offer a route to retrieving control in the application of any law that has to be expressed in scalar terms. It is the way to make a "standard" more "rule-like." Separating out true balancing tests as a subcategory is a necessary step in constructing a good typology of decisional law, a step that the rule/standard distinction does not take.

107 See Leubsdorf, supra note 69, at 544-45 (relating the formula to the dominant test).

108 See id. at 549-50 (arguing that the concern is with wrongful loss of legal rights, not with all harms). But cf. Ofer Grosskopf \& Barak Medina, Repairing (the Doctrine of) Irreparable Harm: Economic Analysis of Preliminary Injunctions, https://works.bepress.com/barak_medina/6/, at $11 \mathrm{n} .30$ (2008) (arguing that the cases take a broader view of the public interests).

109 See also Grosskopf \& Medina, supra note 108 (refining “irreparable harm”).

110 See Hal R. Arkes \& Victoria A. Shaffer, Should We Use Decision Aids or Gut Feelings, in HeURISTICS AND THE LAW 411 (G. Gigerenzer \& C. Engel eds., 2006) (giving a psychological approach).

111 See, e.g., Am. Hosp. Supply Corp. v. Hosp. Prods. Ltd., 780 F.2d 589, 609 (7th Cir. 1986) (Swygert, J., dissenting) ("The judgment of a district judge in an injunction proceeding must be flexible and discretionary-within the bounds of the now settled four-prong test."). By intuition, Swygert would have denied provisional relief to AHS, despite the apparent harm and its good case. In his view, equity dictated that provisional relief should rest on unquantifiable factors, on a feel for the case, on the judge's discretion. The formula would eliminate this beneficial discretion. Finally, Posner's majority did not, and could not, provide exact numbers to work the formula, Swygert said. But see Linz Audain, Of Posner, and Newton, and Twenty-First Century Law: An Economic and Statistical Analysis of the Posner Rule for Granting Preliminary Injunctions, 23 LOY. L.A. L. REV. 1215, 1264 (1990) ("The [formula] demands that judges stop implying that they are engaged in generating anything but an intuitive guess.").

112 See, e.g., Linda S. Mullenix, Burying (with Kindness) the Felicific Calculus of Civil Procedure, 40 VAND. L. REV. 541, 543 (1987) ("This Article argues that Judge Posner's efforts to Benthamize civil procedure are an abomination in theory and practice."); Diego M. Pestana, The "Feel" of a Case: Virtue Decision-Making as the Correct Approach for Deciding Cases in Equity, 31 ST. ThOMAS L. REV. 17 (2018).

113 See Leubsdorf, supra note 69, at 550-56 (discussing estimations).

114 See $i d$. at 566 ("Concealing the difficulties of the preliminary injunction decision under bland generalizations has discouraged lawyers and judges from confronting them.”). 


\section{b. Other Multicriteria Analyses}

As decisions become more complex in terms of multiple factors to consider, and especially as the options among consequences begin to multiply, the law of the future might turn to decisionmaking theory in order to formulate its decisional law. ${ }^{11}$

For example, simple additive weighting, or SAW, requires the decisionmaker to specify the $n$ criteria that guide decision and then to weight them, $w_{1 \rightarrow n}$. The decisionmaker then scores each of the $i$ options with respect to each specified criterion, $s_{1 \rightarrow n}$. That will produce an overall score, $S_{1 \rightarrow i}$, for each option equal to:

$$
S_{x}=w_{1} s_{1}+w_{2} s_{2}+\ldots+w_{n} s_{n}
$$

The decisionmaker finally chooses, from the $i$ choices, the option with the highest overall score. ${ }^{116}$ Thus, SAW can serve as a tool for solving optimization problems.

D. Combinations

I have been dealing in the basic units of decisional law. There are binary and scalar directives. I have suggested subdividing binary directives into those with truly crisp conditions and those that have some spongy conditions. For scalar directives, I have suggested as subdivisions dichotomous v. nondichotomous consequences and exhaustive $\mathrm{v}$. nonexhaustive and nonsystematic $\mathrm{v}$. systematic conditions. That produces eight basic types of directives.

It is essential also to realize that the binary and scalar forms can constitute steps in a bigger decisional process. ${ }^{117}$ There are many kinds of combination. For the simplest example, a binary directive can be subject to an exception, which likewise could be stated as a binary directive. ${ }^{118}$ Or the exception could take the form of a scalar directive. ${ }^{119}$

Similarly, if the law is treating a problem that is admittedly polycentric, it does not follow that the law must be scalar. The law can address some polycentric problems by a complex set of binary directives. ${ }^{120}$

Also, a binary directive could authorize use of a particular scalar directive. In equal protection analysis, for illustration, the decisionmaker is told crisply that if a traditionally suspect classification is involved, then apply strict scrutiny, which is seemingly a scalar directive. ${ }^{121}$

Or a scalar directive may determine a classification, which then operates as a condition in what would otherwise be a binary directive. For example, whether someone is an employee serves as a condition in some crisp-sounding provisions of workers' law, but employee status rests on an

115 See generally LINDELL, supra note 49.

116 See id. at 72-77 (explaining SAW).

${ }^{117}$ Cf. Wilson, supra note 11, at 773 ("This stark dichotomy between archetypal rules and standards can distract us from evaluating courts' frequent application of other 'forms of doctrine' and the foreseeable effects of those other forms. The phrase 'forms of doctrine' refers to such doctrinal structures as exceptions, multiple factor tests, totality of the circumstances tests, 'escape hatches,' and several other hybrid variants (containing elements of both rules and standards), all of which can appear separately or in myriad combinations in a particular substantive area.”).

118 Cf. Frederick Schauer, Exceptions, 58 U. CHI. L. REV. 871, 872, 878 (1991) (characterizing exceptions as a rule intersecting another rule).

${ }^{119}$ Cf. Wilson, supra note 11, at 794-98 (citing exceptions to free speech, such as obscenity).

120 See Schlag, supra note 4, at 422-24 (making this point).

121 See Erwin Chemerinsky, Constitutional Law: Principles And Policies 699 (5th ed. 2015) (“The government must have a truly significant reason for discriminating, and it must show that it cannot achieve its objective through any less discriminatory alternative."). But see Kathleen M. Sullivan, Governmental Interests and Unconstitutional Conditions Law: A Case Study in Categorization and Balancing, 55 ALB. L. REV. 605, 606 (1992) (arguing that strict scrutiny means that the government loses, but at least "[i]ntermediate scrutiny is real balancing"). 
indefinite weighing of factors. ${ }^{122}$ This common sort of combination is important, because it marks the usual route by which "rules" degrade into "standards." It likewise results in a binary directive losing its crispness. ${ }^{123}$

The checklist of a binary directive and a consideration of scalar factors could be linked by "and" or "or" to create necessary or sufficient sets of conditions. Thus, although a complicated law may seem different from the binary and scalar categories, it may not be a new species but instead might simply be a combination of binary and scalar units. ${ }^{124}$

Prime Example of Combination Test: preliminary injunction by series of directives. Some courts have attempted to avoid using a scalar directive for preliminary injunction decisions. What they use is a series of supposedly binary directives in a crude attempt to achieve the right results without all that vagueness.

This approach is called the alternatives test. ${ }^{125}$ If the plaintiff can show probable success on the merits and irreparable injury, the plaintiff should get a preliminary injunction; or if the plaintiff has a reasonably good case but also can show a balance of hardships that tips decidedly toward him or her, then likewise the plaintiff should get that temporary protection. ${ }^{126}$ Thus, two directives are combined as alternative routes to relief. The "bicephalous"127 conditions are stated as if crisp, although the prospect of success is a scalar measure and, more disruptively, the balance of hardships refers to the outcome of an indefinite balancing test.

This is not to say that this judicial approach to preliminary injunctions is a good one. The problem with it is that it tries to capture what is inherently a sliding scale by stating as alternatives the min-max and max-min conditions for the two variables of chance of success and balance of harms. As a result of this clumsiness, it would both give a preliminary injunction where there should be none (e.g., the plaintiff has a slightly better than even case on the merits, where the plaintiff would suffer some minor irreparable injury and where the defendant and the public would suffer major harm pendente lite) and deny a preliminary injunction where there should be one (e.g., a toss-up case, where the balance of hardships tips less than decidedly

122 See Robert N. Covington \& Joseph A. Seiner, Employment LaW IN A Nutshell 20 (4th ed. 2017) ("Many of the protections afforded workers by the statutes and common law doctrines discussed apply only if those workers are 'employees' .... [T] hese definitions are often couched in general terms, providing courts and administering agencies with little concrete guidance about how to work out the details."). Compare RESTATEMENT (SECOND) OF AGENCY \220 (AM. LAW INST. 1958) ("the following matters of fact [(a)-(j)], among others are considered" in defining "employee"), with RESTATEMENT (THIRD) OF AGENCY S 7.07(3)(a) cmt. f (AM. LAW INST. 2006) (stressing control factor).

123 See supra text accompanying note 52.

124 See Brendan T. Beery \& Daniel R. Ray, Five Different Species of Legal Tests-and What They All Have in Common, 37 QUINNIPIAC L. REV. (forthcoming 2019), available at https://ssrn.com/abstract=3240972, at 10-12, 29-30 (misconceiving means-ends tests as a separate species).

125 See Vaughn, supra note 68, at 840. Another combination test is the "gateway factor test." See, e.g., Reilly v. City of Harrisburg, 858 F.3d 173, 179 (3d Cir. 2017) ("Accordingly, we follow our precedent that a movant for preliminary equitable relief must meet the threshold for the first two 'most critical' factors: it must demonstrate that it can win on the merits (which requires a showing significantly better than negligible but not necessarily more likely than not) and that it is more likely than not to suffer irreparable harm in the absence of preliminary relief. If these gateway factors are met, a court then considers the remaining two factors and determines in its sound discretion if all four factors, taken together, balance in favor of granting the requested preliminary relief."); Payne, supra note 75, at 54-56.

126 See, e.g., William Inglis \& Sons Baking Co. v. ITT Cont'l Baking Co., 526 F.2d 86, 88 (9th Cir. 1976) ("This court has adopted the alternative test.”); Sonesta Int'l Hotels Corp. v. Wellington Assocs., 483 F.2d 247, 250 (2d Cir. 1973) ("The settled rule is that a preliminary injunction should issue only upon a clear showing of either (1) probable success on the merits and possible irreparable injury, or (2) sufficiently serious questions going to the merits to make them a fair ground for litigation and a balance of hardships tipping decidedly toward the party requesting the preliminary relief."), as modified by Salinger v. Colting, 607 F.3d 68, 79-80 (2d Cir. 2010) (stressing that the court must deal with likelihoods of harms).

127 OWEn M. Fiss \& DOUg RENDlEMAN, InJUNCTIONS 368 (2d ed. 1984). 
toward the plaintiff). For a small increase in workability, the alternatives test produces nonsensical results. In the long run, the alternatives test is doomed. ${ }^{128}$

\section{CONCLUSION}

The shortcomings of rule/standard are many. First, no agreement exists on what exactly this terminology means. Second, all of its possible meanings constitute a continuum, and spectral distinctions are usually difficult to draw. Third, the rule/standard line on any such continuum is not sharp in actuality. Fourth, however the line is drawn, some rules are very standard-like, and some standards are quite rule-like. Fifth, the classification itself, as opposed to its evocation, does not ultimately aid legal actors in formulating or applying the law.

There exists a clearer and more useful distinction: binary and scalar directives. The essence of this distinction is easy to grasp and employ. If the directive comprises a checklist of one or more binary conditions, then it is a binary directive. If instead the directive calls for consideration of scalar factors, it is a scalar directive. Binary/scalar could be as evocative an image as is rule/standard. On the one hand, rule/standard evokes some sense of how much the lawmaker has pinned things down. On the other hand, "binary" gives this sense of a rule, but the characteristic of crispness also reminds us that the decisional law can fail to pin things down if the condition is softly crisp. "Scalar" likewise conveys the unsettledness of a standard, but also recognizes that systematized directives can reduce indefiniteness and retrieve the aim of pinning things down.

Moreover, binary/scalar is a superior distinction for analysis. First, binary/scalar is a clear and clean distinction. Second, it is a telling distinction that represents a significant difference between the components that compose the law. Third, it tells the law-applier much about whether the law-giver tried to pin things down. Fourth, it conveys a better sense of the tools at hand for the law-giver's pinning down the law-applier, and thus enables the tools' deployment in an optimal way. Fifth, it allows the drawing of meaningful subdivisions that bring to the fore the choices in shaping that law: for example, a true balancing test explicitly or implicitly presents an exhaustive listing of quantifiable and commensurable factors to be weighed against one another-and offers a route to retrieving control in the application of any law that has to be expressed as a scalar directive.

A running example to illustrate the superiority of binary/scalar comes from injunctive relief. The test for a temporary restraining order was the binary condition of "irreparable harm," but it has disintegrated in practice to conform to the prevailing test for a preliminary injunction. Throughout the Article, the diversity among the tests for a preliminary injunction have revealed the essential struggle between the necessary flexibility for infinitely variable situations and the need for appropriately corralling the judges' discretion. From ancient roots of unrestrained discretion, the test for a preliminary injunction has evolved in recent decades from a sequential test of four supposedly binary conditions to the indefiniteness of a sliding-scale approach that balances the four factors, back to a hopeless stab at crispness in the form of the alternatives test, which tries to state alternative combinations of situational facts that warrant provisional relief. The best test, to my mind, emerges as a systematized form of scalar directive - a true balancing test - that asks if the expected costs of a potentially wrongful denial exceed the expected costs of a potentially wrongful grant of a preliminary injunction. But whether the reader agrees or disagrees on the substance of the best preliminary injunction test, the reader should see the inadequacy of rule/standard for this analysis of optimal form: all the competing tests would probably be currently categorized as "standards."

In sum, through general theorizing and by specific examples, this Article supports binary/scalar as a top-level distinction among the forms of decisional law that works better than the current conception of rule/standard. However, I am not suggesting casting rule/standard aside as a way of classifying decisional law. For one thing, it is too much a part of our vocabulary. It is also a usefully evocative image. I am instead suggesting binary/scalar as a redefinition of "rules" and

128 See Am. Beverage Ass'n v. City of S.F., 916 F.3d 749 (9th Cir. 2019) (en banc) (applying a four-actor test); Citigroup Glob. Mkts., Inc. v. VCG Special Opportunities Master Fund Ltd., 598 F.3d 30, 35 (2d Cir. 2010) (arguing for "flexibility in the face of varying factual scenarios"); William Hughes Mulligan, The Second Circuit Review-1975-76 Term-Foreword: Preliminary Injunction in the Second Circuit, 43 BROOK. L. REV. 831 (1977). 
"standards." That is, binary/scalar should provide the metarule for categorizing between rule and standard.

How would this metarule work? While lawmaking, the law-giver would tentatively decide whether the law-applier should make binary decisions or should roughly measure quantities often in relation to one another. The law-giver would do so on notions of desirable division of labor between law-giver and law-applier. In finalizing the form of the law, the law-giver could consider the traditional rule/standard feelings to decide just how directive it could and should be-such as realizable benefits of workable certainty or flexible accuracy, relative costs of promulgation and application, and institutional capacities. On the one hand, if a tentatively binary directive ends up with soft conditions, the law-giver might decide to switch to an honestly scalar directive. It should not try to deceive by constructing a "rule." On the other hand, if a scalar directive needs to be more constraining, the lawmaker should move toward a systematized scalar directive, perhaps a true balancing test, rather than deforming the decisional law by trying to convert the formulation into a "rule." Thus, familiar rule/standard feelings can help in deciding how to deploy binary and scalar directives. 